\title{
The role of powder physicochemical properties on the extinction performance of an extinguishing powder for sodium fires
}

\author{
Kusumanindyah Nur ${ }^{\mathrm{a}, \mathrm{b}}$, Brissonneau Laurent ${ }^{\mathrm{a}, *}$, Gilardi Thierry ${ }^{\mathrm{a}}$, Gatumel Cendrine ${ }^{\mathrm{b}}$, \\ Berthiaux Henri ${ }^{\mathrm{b}}$
}

${ }^{\mathrm{a}}$ CEA, DEN, Cadarache DTN/SMTA/LMCT, F-13108 Saint-Paul-lès-Durance, France
${ }^{\mathrm{b}}$ RAPSODEE, CNRS UMR 5302, Ecole des Mines d'Albi-Carmaux, F-81013 Albi, France

\section{Keywords:}

Sodium

Fire

Powder

Physicochemical

Extinction

\begin{abstract}
A B S T R A C T
The French Atomic and alternative Energy Commission (CEA) aims to reuse its sodium fire (carbonate base) extinguishing powder after long term storage (stock from the dismantlement of its old sodium facilities). As the composition of the powder appears to change during the storage, the efficiency on the extinction as a function of the physicochemical properties was questioned. Small sodium fire extinction experiments were carried out with powders of different compositions. The results demonstrated a dominant role of water of crystallization on the extinction. Two steps are proposed for the extinction mechanism that includes: (1) the formation of liquid sodium hydroxide and (2) the melting of carbonate mixture at eutectic composition. The sodium hydroxide behaves as a protective layer and insulates the sodium surface from prolonged contact with oxygen. Consequently, it provides rapid decrease of temperature, unlike the slow melting of carbonates eutectic and its porous layer formed due to its higher viscosity. The presence of trona (aging product) does not alter the extinction capacity of the powder. To extrapolate the results to large fires, $35 \mathrm{~g}$ of water of crystallization are necessary to extinguish $1 \mathrm{~m}^{2}$ of sodium pool fire. Finally, the particle size appears to be a non-significant parameter to the quality of extinction except for the spreading performance.
\end{abstract}

\section{Introduction and background}

Sodium has attractive properties that make it suitable to be used as a coolant in Sodium cooled Fast Reactors (SFR): large temperature range in the liquid state $\left(97.8-883^{\circ} \mathrm{C}\right.$ at atmospheric pressure), excellent thermal conductivity, low activation under neutron flux, compatibility with stainless steels (Sakamoto, 2013). However, it is also a very strong reductant, and its significant chemical reactivity with water and air requires specific operating conditions and safety equipment. In case of leak out of the circuits, liquid sodium may ignite spontaneously upon contact with air or oxygen above $130{ }^{\circ} \mathrm{C}$. Thus, all the sodium circuits are usually operated under inert atmosphere. A leak detection system on the pipe welding is also necessary to prevent and limit the consequences of a sodium fire after sodium release (Sylvia, 2012). Furthermore, efficient solutions for the mitigation of sodium fire must be developed to satisfy safety recommendations, and in particular to achieve its rapid extinction.

Many researches have proposed various extinction methods, either by passive devices such as leak collection trays (Diwakar, 2011; Newman, 1979; Schneider, 2009) or by active means like extinguishing powders (Newman, 1979; Jeong, 2002; Reuillon et al., 1979; Sarrut, 1979). In 1978, CEA developed an extinguishing powder (Reuillon et al., 1979), the so called Marcalina ${ }^{\circledR}$, which was proven to be very effective to put out sodium fires at low and high temperatures. Small quantity ( $5 \mathrm{~g}$ ) of powders were needed to extinguish small scale sodium fires $\left(10 \mathrm{~g}\right.$ of $\mathrm{Na}$ ) at temperatures of $550{ }^{\circ} \mathrm{C}, 301{ }^{\circ} \mathrm{C}$, and $275^{\circ} \mathrm{C}$ (Reuillon, 1976). This powder is composed mainly of lithium carbonate $\left(\mathrm{Li}_{2} \mathrm{CO}_{3}\right)$ and low-hydrated sodium carbonate $\left(\mathrm{Na}_{2} \mathrm{CO}_{3}, \mathrm{H}_{2} \mathrm{O}\right)$ in a near eutectic proportion, with a melting temperature of $498^{\circ} \mathrm{C}$ (Reuillon et al., 1979), and contains graphite $(\approx 10 \% \mathrm{w})$. It was produced in France (by CACI) between the 1980s to the 1990s, but the production was then ceased in absence of new industrial order. The opportunity to reuse these powders raised the questions about their capacity to extinguish a sodium fire after long term storage and to ensure the safety of sodium facilities (experimental loops or reactors) for projects in the future.

Three powders named powders A, B, and C, were chosen as representative samples from different storage locations. The physicochemical analyses related to these powders were conducted and discussed in Kusumanindyah et al. (2015); they are summarized in

\footnotetext{
* Corresponding author.

E-mail address: laurent.brissonneau@cea.fr (B. Laurent).
} 
Table 1

Summary of the physicochemical results of powders A, B, and C (Kusumanindyah et al., 2015) vs specification from literature (Reuillon et al., 1979; Reuillon, 1976).

\begin{tabular}{|c|c|c|c|c|}
\hline Characteristics & Powder A & Powder B & Powder C & Specification \\
\hline \multicolumn{5}{|l|}{ Physical } \\
\hline $\begin{array}{l}\text { - LASER } \\
\text { Granulometry }\end{array}$ & $5.6 \mu \mathrm{m}$ & $30.3 \mu \mathrm{m}$ & $7.4 \mu \mathrm{m}$ & \multirow[t]{3}{*}{$<160 \mu \mathrm{m}$ (Reuillon, 1976) } \\
\hline $\begin{array}{l}\text { - FT4 powder } \\
\text { rheometry }\end{array}$ & Cohesive $(++)$ & $\begin{array}{l}\text { Cohesive }(-) \\
\approx \text { easy flow }\end{array}$ & Cohesive $(+)$ & \\
\hline - SEM & $\begin{array}{l}\text { Regular shaped of } 5 \mu \mathrm{m} \text { rod-like, } \\
\text { with larger particles length } \\
(20 \mu \mathrm{m})\end{array}$ & $\begin{array}{l}\text { Irregular shaped of } 100 \mu \mathrm{m} \text { particles } \\
\text { (agglomerated needle shape } \\
\text { particles) }\end{array}$ & Similar to powder A & \\
\hline \multicolumn{5}{|l|}{ Chemical } \\
\hline & $(\% w)$ & $(\% w)$ & $(\% w)$ & $(\% w)$ \\
\hline - $\mathrm{XRD}$ & - $\mathrm{Na}_{2} \mathrm{CO}_{3} \cdot \mathrm{H}_{2} \mathrm{O}: 31$ & - $\mathrm{Na}_{2} \mathrm{CO}_{3} \cdot \mathrm{H}_{2} \mathrm{O}: 29$ & - $\mathrm{Na}_{2} \mathrm{CO}_{3} \cdot \mathrm{H}_{2} \mathrm{O}: 16$ & Graphite filtration \& AAS (Kusumanindyah, \\
\hline - TGA & $-\mathrm{Li}_{2} \mathrm{CO}_{3}: 33$ & $-\mathrm{Li}_{2} \mathrm{CO}_{3}: 38$ & $-\mathrm{Li}_{2} \mathrm{CO}_{3}: 35$ & 2016) \\
\hline$\bullet \mu \mathrm{GC}$ & - $\mathrm{LiNaCO}_{3}: 26$ & $-\mathrm{LiNaCO}_{3}: 0$ & - $\mathrm{LiNaCO}_{3}: 18$ & - $\mathrm{Na}_{2} \mathrm{CO}_{3}: 43.2$ \\
\hline - Graphite filtration & - Trona: 1 & - Trona: 20 & - Trona: 26 & $-\mathrm{Li}_{2} \mathrm{CO}_{3}: 43$ \\
\hline \multirow[t]{5}{*}{$\bullet$ AAS } & - Graphite: 9 & - Graphite: 8 & - Graphite: 5 & - Graphite: 9 \\
\hline & - Free water: 0 & - Free water: 4 & - Free water: 0 & \\
\hline & water of crystallization: 4.7 & water of crystallization: 8.4 & water of crystallization: & water of crystallization: $3.5-5.4( \pm 1)$ \\
\hline & & & 7.5 & (Reuillon, 1976) or 7 (from $48 \% w$ \\
\hline & & & & $\mathrm{Na}_{2} \mathrm{CO}_{3} \cdot \mathrm{H}_{2} \mathrm{O}$ in Reuillon et al. (1979)) \\
\hline DSC & $\mathrm{T}_{\text {fusion }}=498.9^{\circ} \mathrm{C}$ & $\mathrm{T}_{\text {fusion }}=499.4^{\circ} \mathrm{C}$ & $\mathrm{T}_{\text {fusion }}=498.5^{\circ} \mathrm{C}$ & $\mathrm{T}_{\text {fusion }}=500^{\circ} \mathrm{C}$ \\
\hline
\end{tabular}

${ }^{a}$ Physicochemical analyses of the specification were taken from literature (Reuillon et al., 1979; Reuillon, 1976).

Table 1. The results were compared to the formulation specifications provided in the literature. The chemical analysis with X-Ray Diffraction (XRD) highlights the presence of "trona" (Na2CO3-NaHCO3.2H2O) and $\mathrm{LiNaCO}_{3}$, two compounds that are not mentioned in the patent. Coupled Thermo Gravimetric Analysis (TGA)-micro Gas Chromatography $(\mu \mathrm{GC})$ and Atomic Absorption Spectroscopy (AAS) were able to perform quantitative analysis of these powders. Several physical analyses (Scanning Electron Microscopy (SEM), LASER particle size analysis, FT4 powder rheometry) were also conducted in our previous work to characterize the powders (Kusumanindyah et., 2015). Some results are shown in Supplementary materials 1 . The content in water of crystallization originates from $\mathrm{Na}_{2} \mathrm{CO}_{3}, \mathrm{H}_{2} \mathrm{O}$ and trona (the two water containing compounds) contained in the powders.

Two categories of powders could be distinguished based on their water of crystallization content (specifications of the manufacturer ranged between 3.5 and $5.4( \pm 1) \% \mathrm{w})$ :

- Powder within specifications (i.e. powder A), composed of a high amount of $\mathrm{LiNaCO}_{3}$ and a small amount of trona. It had small particle sizes and demonstrated cohesive properties.

- Powders out of specifications (i.e. powders B and C), composed of a high amount of trona and a small amount of $\mathrm{LiNaCO}_{3}$. Powder B had relatively large particles (easy flowing), while powder $C$ had small particles but was considered to be less cohesive than powder A.

We found (Kusumanindyah et al., 2015) that trona $\left(\mathrm{Na}_{2} \mathrm{CO}_{3} \cdot \mathrm{NaHCO}_{3} \cdot 2 \mathrm{H}_{2} \mathrm{O}\right)$ was actually an aging product whose formation depends highly on relative humidity and on the presence of $\mathrm{CO}_{2}$. Meanwhile lithium sodium carbonate $\left(\mathrm{LiNaCO}_{3}\right)$ was produced by the mechanochemical reactions that happened during fabrication through the grinding process (due to the heat released throughout this operation). However a high humidity condition and limited presence of $\mathrm{CO}_{2}$ was favorable to its decomposition. These results implied that storage condition could influence the powder composition. The analysis of powder $\mathrm{B}$ revealed that it experienced both reactions of trona formation and $\mathrm{LiNaCO}_{3}$ decomposition, while the latter was unachieved (likely slower than the former one) in case of powder C.

In this paper, powders of different compositions (A, B, C and other synthetic ones) are compared through sodium fire extinction tests. This study aims to understand the role of each component on the extinction performance, particularly in relation to the water of crystallization content, which may be increased by the presence of trona or the decomposition of $\mathrm{LiNaCO}_{3}$. The effect of melting temperatures and especially of an easier carbonate melting (due to the presence of $\mathrm{LiNaCO}_{3}$ in the mixture) is also studied. As its presence in the powder is likely unintentional, due to a co-grinding of $\mathrm{Na}_{2} \mathrm{CO}_{3}, \mathrm{H}_{2} \mathrm{O}$ and $\mathrm{Li}_{2} \mathrm{CO}_{3}$ during powder processing, the relevancy of this compound in the powder was questionable.

The aim of these tests was to provide valuable information to determine optimized powder specifications and to propose a phenomenological description of the extinction mechanism with Marcalina powder.

\section{Materials and methods}

\subsection{Materials}

Powders A, B, and C were used as the Marcalina powder samples representative of the different storage conditions. Powder A had the smallest content of trona with only $4.7 \mathrm{w} \%$ of water content. Powder B did not contain $\mathrm{LiNaCO}_{3}$ but more water (partly in the form of water of crystallization contained in: $29 \mathrm{w} \%$ of $\mathrm{Na}_{2} \mathrm{CO}_{3}, \mathrm{H}_{2} \mathrm{O}$ and $20 \mathrm{w} \%$ of trona, as well as an added $4 \mathrm{w} \%$ of free water). It also contained $38 \mathrm{w} \%$ of $\mathrm{Li}_{2} \mathrm{CO}_{3}$, and $8 \mathrm{w} \%$ graphite). Powder $\mathrm{C}$ contained both trona and $\mathrm{LiNaCO}_{3}$ with $7.5 \mathrm{w} \%$ of water of crystallization content.

Besides these powders, synthetic powders of different chemical compositions were also prepared for extinction tests dedicated to the study of different parameters. Fig. 1 provides the classification of the different synthetic powders produced along with the different parameters to be studied for the comprehension of extinction mechanism. The role of the water of crystallization was mainly studied through the comparison of Powders 1, 2, 3 and 4 (from $0 \% \mathrm{w}$ to $18.1 \% \mathrm{w}$ of water of crystallization.

The role of the melting of carbonates (at eutectic temperature) was studied through the comparison of Powders 5, 6 and 7 (with only sodium carbonate, an eutectic mixture of sodium and lithium carbonates, or with the $\mathrm{LiNaCO}_{3}$ compound, respectively). These powders contained no water of crystallization. The eutectic and $\mathrm{LiNaCO}_{3}$ melting temperatures are $499.754 \pm 0.057^{\circ} \mathrm{C}$ and $500.757 \pm 0.005{ }^{\circ} \mathrm{C}$ respectively (Cairns and Macdonald, 1962).

The influence of spreading method was studied through the comparison of Powders 8, 9, 10 and 11, which contains water of crystallization amounts varying from $2.9 \% \mathrm{w}$ to $13.2 \% \mathrm{w}$.

The raw materials were first milled in a planetary ball mill and then 

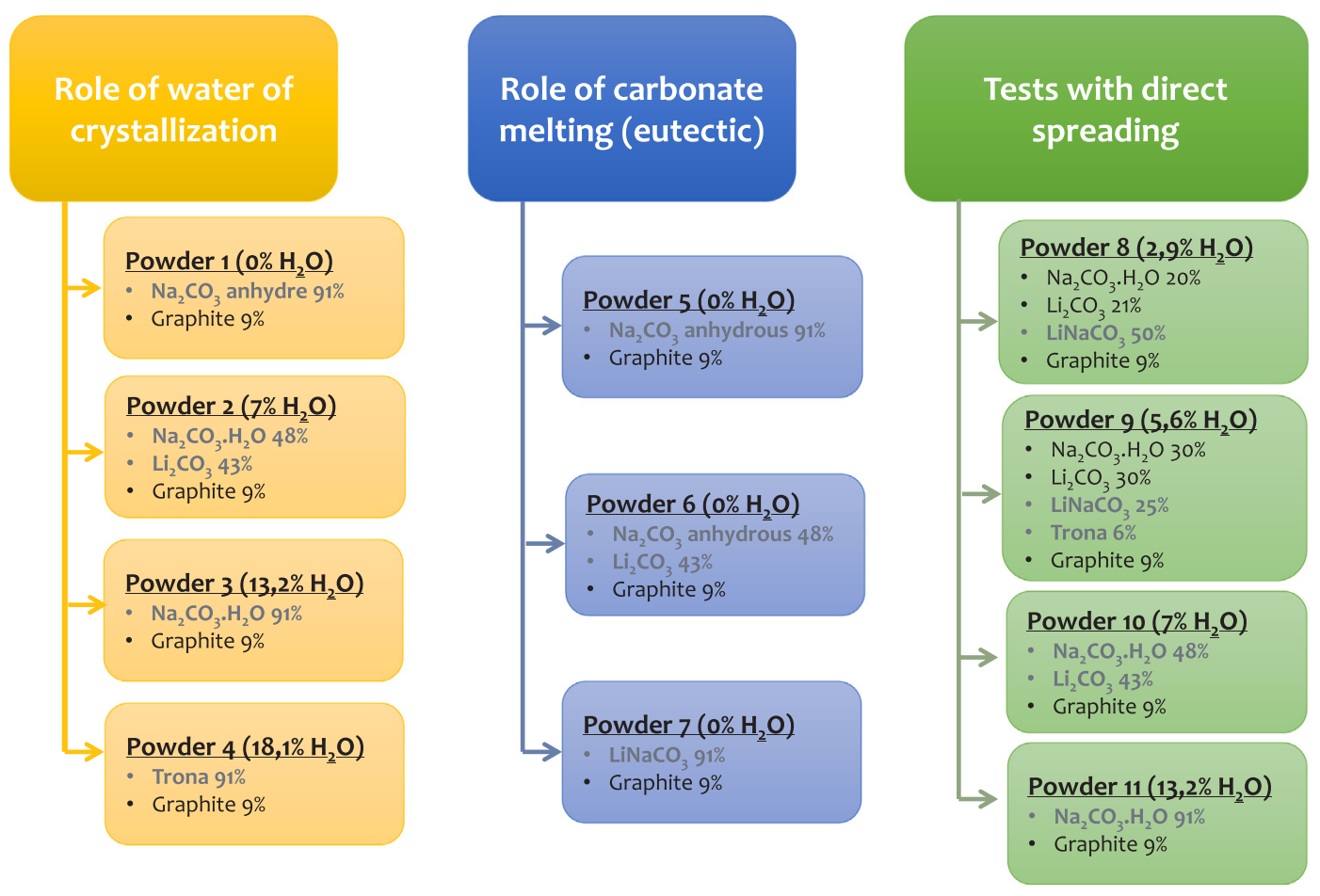

Fig. 1. Synthetic powders tested for sodium pool fire extinction tests in Chris(X)ti-Na.

sieved: only the particles of size $\leq 63 \mu \mathrm{m}$ (as mainly specified for Marcalina) were retained. The sieved materials were then mixed in a Turbula $^{\circledR}$ T2F (WAB society), to get homogenized final powders. Each sample produced was analyzed by XRD to verify its composition.

\subsection{Experimental set up and procedure}

The Chris(X)ti-Na experiment was developed to study the extinguishing properties of the powders in a small sodium pool fire (Kusumanindyah, 2016). The sodium was conserved in an insulated stainless steel crucible covered with a lid where temperature could be raised up to $500{ }^{\circ} \mathrm{C}$ using an electric hotplate. The surface area of liquid sodium in the crucible was $19.6 \mathrm{~cm}^{2}$. Ten grams of sodium were used in each experiment, $(0.7 \mathrm{~cm}$ height). As soon as the sodium temperature reached $450{ }^{\circ} \mathrm{C}$, the air circulation (aspiration system) was started and the inerting argon gas circulation was stopped. The crucible lid was then removed, allowing a direct contact of liquid sodium with air. Even if there was a thin sodium oxide layer observed on the surface of liquid sodium, the fire took place in a few seconds. After complete ignition of the sodium fire (when sodium temperature is around $540^{\circ} \mathrm{C}$ ), the powder in the tank located above the sodium container was spread.

Two spreading methods (Fig. 2a) were studied using two powder spreader devices, (a) a powder vibrator for gradual spreading and (b) a powder trapdoor for instantaneous spreading.

The vibrating sieves allowed the powder to be spread continuously and progressively, which represents the actual application during extinction using powder extinguisher. However, a rather uneven spreading was obtained. In this case, the vibration was stopped when no more flame is observed. The difference between the initial mass of powder stored in the spreader tank with the one lost during the experiment indicated the mass of the powder used for extinction.

Whereas the trapdoor system (in a form of a manually mobile blade) allowed powder to be spread all at once, with the same quantity of powder $(5 \mathrm{~g})$ used for each test, so that the efficiency of the powders could be compared in similar conditions. Therefore, the quantity of powder employed as well as the extinction time might be more accurate and then easier to be justified. In case of fire persistence, additional powder was added manually until extinction was obtained. The powder compositions ( $\left.\mathrm{n}^{\circ} 8-11\right)$ were chosen in order to check, in these spreading conditions, the influence of two parameters: the water and $\mathrm{LiNaCO}_{3}$ contents.

Fire extinction for both systems was observed by the temperature measurements and by video recording of the experiments. Four thermocouples were placed inside the sodium container at four different

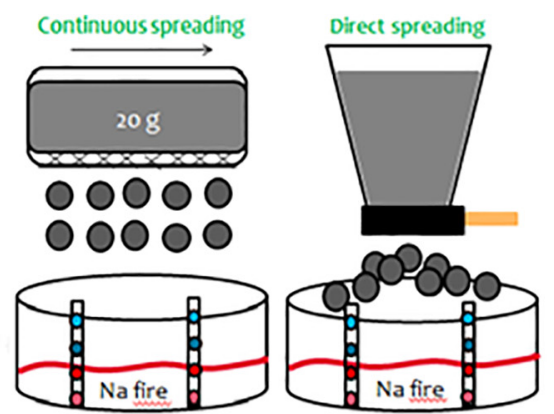

(a)

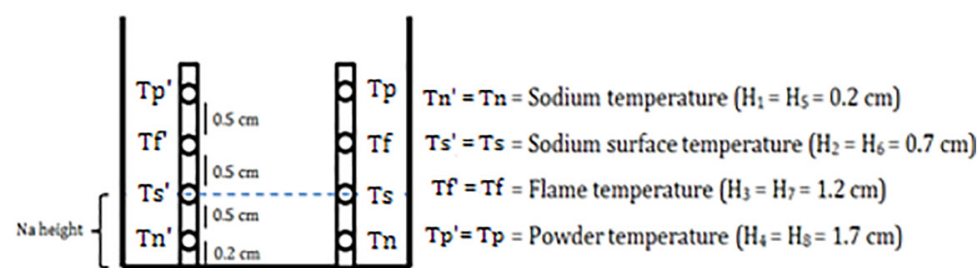

(b)

Fig. 2. (a) Two spreading methods used in sodium extinction test (b) The position of thermocouples inside the sodium receptacle. 
significant levels: inside the sodium, at the sodium pool surface, in the flame (the flame of a sodium fire is located few millimeters above its surface (Reuillon, 1976; Newman and Payne, 1978) and in the powder. The positions of the thermocouples are detailed in Fig. 2b. The extinction residue was then cooled down to room temperature for sampling and XRD analysis. For some powders, two tests were conducted.

\subsection{Methods of characterization and analysis of experimental results}

The temperature profile of thermocouples was synchronized with the video camera, which allowed visualizing the local combustion and extinction phenomena. The recorder evolutions were composed of two different steps: combustion and extinction. The chemical characterization of the extinction residue by XRD was realized in the laboratory after sampling, when the materials were at around $25^{\circ} \mathrm{C}$.

\subsubsection{Combustion}

Generally, two types of sodium combustion were observed in the experiments, the combustion that was preceded by an oxidation phase without any flame (delay of ignition) and the spontaneous combustion (without delay of ignition). The difference of ignition delay was observed from the video and thermocouple recordings. The ignition was relatively fast with an average time of $2 \mathrm{~s}$ on each test as observed in the video. However, it was detected much later when measured by thermocouples. This is due to the nodulation (preferential ignition point) on the sodium surface that occurred in places at different distances from thermocouples locations.

\subsubsection{Extinction}

The powder spreading started as soon as $T_{n}$ (temperature in the sodium pool) and $\mathrm{T}_{\mathrm{s}}$ (temperature at the sodium surface) reached a temperature around $500{ }^{\circ} \mathrm{C}$. This temperature was chosen as it represents the average sodium temperature operating condition in the reactor. Besides, this ensured that the temperature at which the spreading starts was always the same. However, it must be emphasized that the flame temperatures indicated by both $\mathrm{T}_{\mathrm{f}}$ (temperature in the flame) and $T_{p}$ (temperature in the powder layer after spreading) before spreading might be different. Several conventions were adopted to simplify the analysis of results:

- All of the thermocouples were immerged in the powder at the end of extinction.

- $\mathrm{T}_{\mathrm{f}}$ and $\mathrm{T}_{\mathrm{p}}$ were chosen as the best representation of the temperature profile indicating extinction (interpreted by the decrease of temperature). The rate of temperature decrease and/or increase was calculated by dividing the temperature difference by the time during which it was observed.

- The extinction was considered to be achieved based on the absence of flame checked from visual observation using video recording.

\section{Experimental results}

\subsection{Role of water of crystallization (powders 1-4, A, B and C)}

A series of extinction tests were carried out to study the influence of water of crystallization on the capacity of extinction for continuous spreading conditions. Typical temperature monitoring and images of the fire and its extinction are shown in Fig. 3 for powder 1 (no water of crystallization) and in Fig. 4 for powder $3(13 \mathrm{w} \%$ of water of crystallization). The results of these tests are tabulated in Table 2 and the comparison of the temperature monitoring of the thermocouple $\mathrm{Tp}$ for all the powders in Fig. 5. Shots of the video recording illustrating the evolution of the sodium fire for powder 1 are reported in Fig. 6a-e.

Powders with no or a low content of water $(1, \mathrm{~A})$ struggled to melt at the sodium surface (Fig. 6a-c), the temperature decrease was slow (see Fig. 5) and manual intervention was required to cover with powder re-ignition points near the border (6e). The higher was the water content, the faster was the temperature decrease and the shorter the time needed to extinguish the fire ( $423 \mathrm{~s}$ for powder $1,44 \mathrm{~s}$ for powder 4 ). The final quantity of water of crystallization used for complete extinction is quite similar in all the experiments (from 0.5 to $0.9 \mathrm{~g}$ ).

For the powders with higher water contents ( $\mathrm{n}^{\circ} 3$ and 4 ), two other phenomena are observed: a fast temperature increase in the powder at the beginning of the spreading and higher flames (about $5 \mathrm{~cm}$, while sodium fire flames are very short, $<2 \mathrm{~cm}$ ). For powder 4 , flames could be observed during $18 \mathrm{~s}$. Meanwhile, this phenomenon was observed for powder 3 only during the high spreading rate experiment. This flame locally induced temperature increase for the highest thermocouple $\mathrm{Tp}$. It should also be noticed for these two high water content powders that, after extinction, the temperature in the powder $\left(300-450^{\circ} \mathrm{C}\right)$ was much lower than the temperature at the surface of the sodium (being constant at about $\left.530^{\circ} \mathrm{C}\right)$. XRD analysis of the extinction residue showed higher peaks of sodium hydroxide $(\mathrm{NaOH})$ than for the powders of lower water contents.

\subsection{Role of $\mathrm{LiNaCO}_{3}$ compound (powders 5-7)}

The results of the tests are reported in Table 2. All of the three powders $\left(n^{\circ} 5,6,7\right)$ encountered difficulties to melt at the sodium surface. Therefore, the fire could not be extinguished on part of the surface and a temperature rise of $9.3^{\circ} \mathrm{C} / \mathrm{s}$ was even observed in case of powder 6 (eutectic mixture of $\mathrm{Li}$ and $\mathrm{Na}$ carbonates). Operator intervention was needed to achieve complete extinction in all cases. In case of powder 6 , a large amount of $\mathrm{LiNaCO}_{3}$ was found in the residue by XRD, which means that the compounds likely melt (at least partially). Indeed, dedicated DSC experiments (cf. Fig. A-3 Supplementary Materials 1) and XRD analyses on eutectic composition mixtures showed that no reaction occurs when $\mathrm{Na}_{2} \mathrm{CO}_{3}$ and $\mathrm{Li}_{2} \mathrm{CO}_{3}$ mixture are heated under $500{ }^{\circ} \mathrm{C}$, and $\mathrm{LiNaCO}_{3}$ was found only after heating above the eutectic point $\left(500{ }^{\circ} \mathrm{C}\right)$. The performance of the powder 7 with $\mathrm{LiNaCO}_{3}$ was only slightly better compared to the two others, so this compound does not appear to play a predominant role on the sodium fire extinction.

These tests illustrated that having the carbonates in the form of a "pre-mixed' compound $\mathrm{LiNaCO}_{3}$ did not help in accelerating the melting of the powder. Anhydrous carbonate compounds melting seemed to happen slower than the ones containing water of crystallization. Moreover, during cooling phase, the solidification of melted $\mathrm{LiNaCO}_{3}$ formed a porous layer at the sodium surface. This might result in cracking of these layers, thus provoking re-ignition as the temperature on the surface was still high (close to $500^{\circ} \mathrm{C}$ ).

\subsection{Complementary extinction tests under direct spreading conditions (powders 8-11)}

Powders 8, 9, 10 and 11 were used to test the influence of direct spreading conditions towards the extinction performance, and particularly on temperature evolution. The results are reported in Table 2.

The time of extinction and the quantity of powder needed to achieve the extinction decreased with higher content of water of crystallization in the powder, as shown in the tests with continuous spreading. $\mathrm{NaOH}$ and $\mathrm{LiNaCO}_{3}$ were found in the residues, but more $\mathrm{NaOH}$ was observed with powder 11, which had the highest water content (it should be noted that $\mathrm{NaOH}$ was not only a reaction product but could have been formed after the experiment by the contact of the residual sodium with moisture).

In the case of the three powders with the lower water of crystallization contents (8, 9 and 10), several temperature rises and re-ignition, followed by temperature decrease, were observed. Re-ignitions happened, needing additional powder to achieve a complete extinction. Powder 8 with $2.9 \%$ w water of crystallization slowly melted on the sodium surface, the crust was porous, leading to several re-ignitions and temperature rises. 


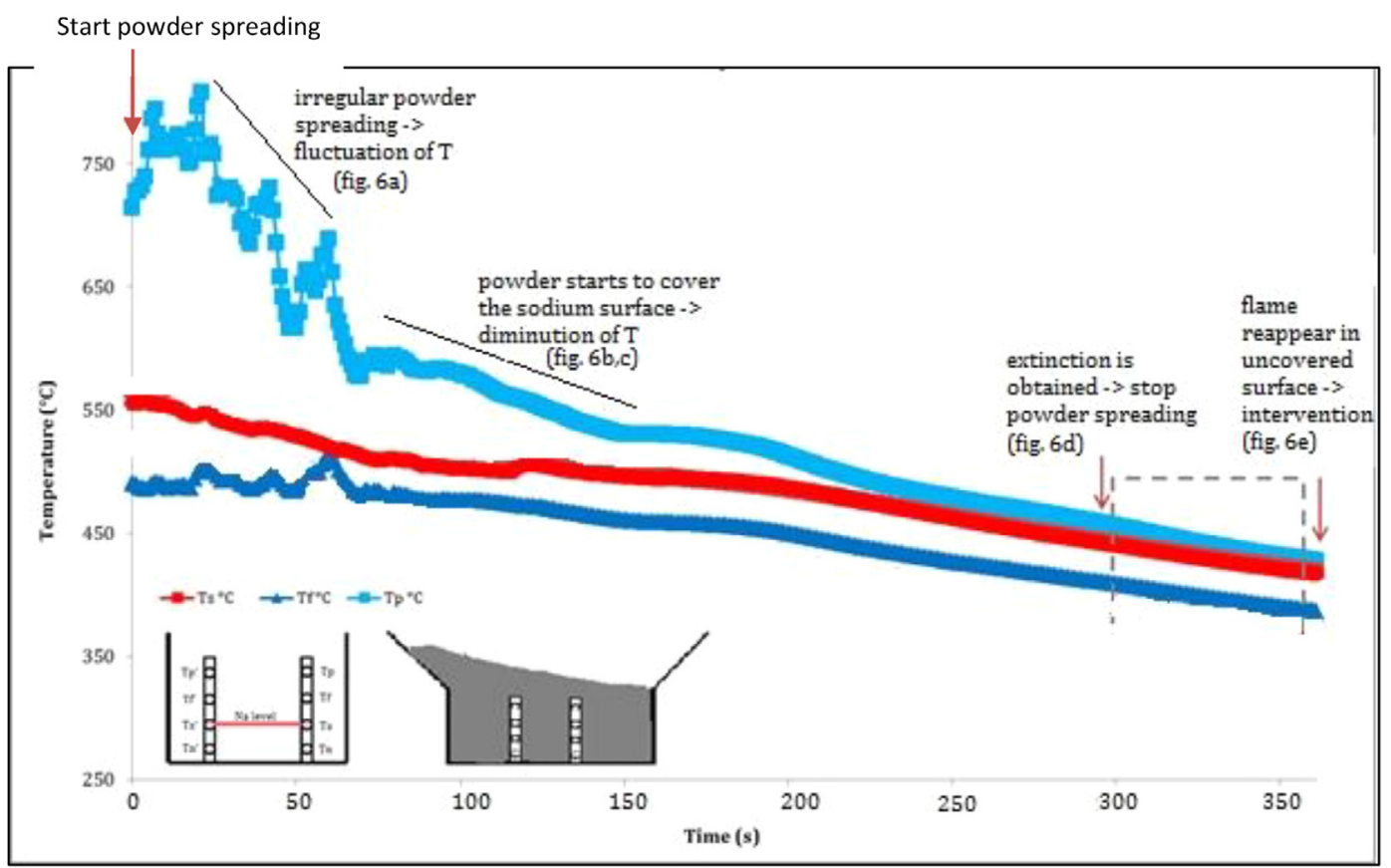

Fig. 3. The temperature of the Chris(X)ti-Na experiment with continuous spreading during extinction using powder 1 (and period corresponding to video shots in Fig. 6a-e).

In the case of powder 11 with $13.2 \mathrm{w} \%$ of water of crystallization, a high vigorous flame was observed when the powder felt onto the fire for around $47 \mathrm{~s}$, with a high rate of temperature increase. The powder melted rapidly, with a rate of temperature decrease ten times faster than for the other powders.

The evolution of flame extinction using powder 11 is shown in Fig. $6 \mathrm{f}-\mathrm{j}$. A high and sudden flame is produced after spreading (6f), which is dominated by a yellow color with a bright white center, for several seconds ( $6 \mathrm{f}$ and $\mathrm{g}$ ). The bright center slowly disappeared after the melting of powder at the surface $(6 \mathrm{~h}$ and i) that might be attributed to the formation of sodium hydroxide.

During extinction with powder $10\left(7 \% \mathrm{H}_{2} \mathrm{O}\right)$, a relatively small flame as compared to the one with powder $11\left(13.8 \% \mathrm{H}_{2} \mathrm{O}\right)$ was observed. It had the same bright white light in the center, but appeared to be shorter

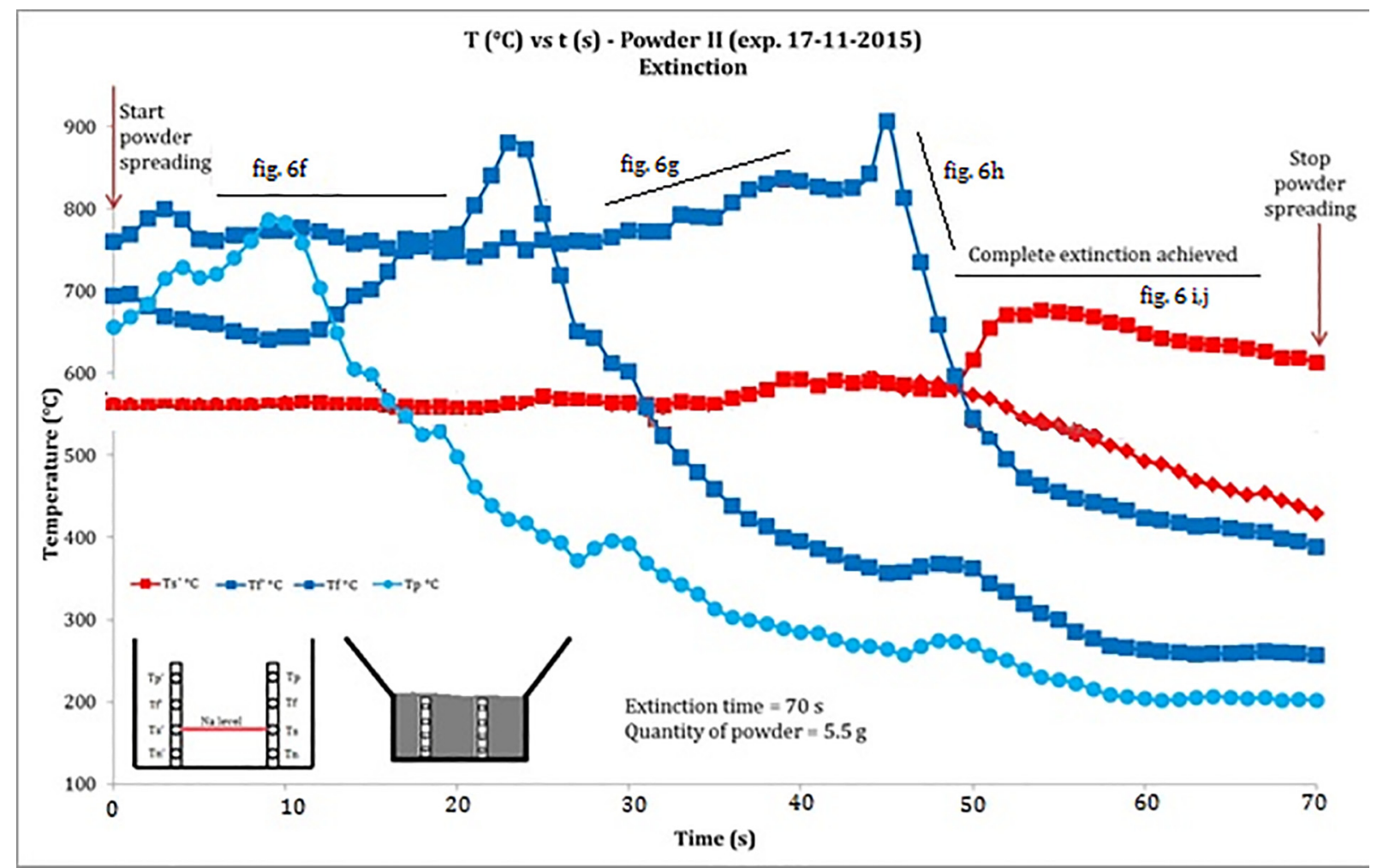

Fig. 4. The temperature of the Chris(X)ti-Na experiment with continuous spreading during extinction using powder 3 (and periods corresponding to video shots in Fig. 6f-j). 
Table 2

Results of small sodium pool fire tests.

\begin{tabular}{|c|c|c|c|c|c|c|c|}
\hline Study & Powder & $\begin{array}{l}\text { Significant } \\
\text { characteristics }\end{array}$ & $\begin{array}{l}\text { Extinction rate (Tp) } \\
{ }^{\circ} \mathrm{C} \cdot \mathrm{min}^{-1}\end{array}$ & $\begin{array}{l}\text { Time for } \\
\text { extinction (s) }\end{array}$ & $\begin{array}{l}\text { Mass }(\mathrm{g} \text { ) for extinction (water of } \\
\text { crystallization) }\end{array}$ & High flame & $\begin{array}{l}\text { XRD results of } \\
\text { residues }\end{array}$ \\
\hline \multirow{9}{*}{$\begin{array}{l}\text { Role of water of } \\
\text { crystalliza-tion }\end{array}$} & 1 & $0 \mathrm{w} \% \mathrm{H}_{2} \mathrm{O}$ & 0.4 & 295 & $8.6(0)$ & No & N.O. \\
\hline & A & $4.7 \mathrm{w} \% \mathrm{H}_{2} \mathrm{O}$ & 0.4 & 423 & $10.4(0.5)$ & No & $\begin{array}{l}\mathrm{NaOH}(-) \\
\mathrm{Na}\end{array}$ \\
\hline & 2 & $7 \mathrm{w} \% \mathrm{H}_{2} \mathrm{O}$ & 3.4 th. 2.3 & $173 /$ & $10.9(0.8) /$ & No & N.O. \\
\hline & $2^{\text {nd }}$ run & High spread & 3.8 th. 9.2 & 20 & $7.3(0.5)$ & No & N.O. \\
\hline & $\mathrm{C}$ & $7.5 \mathrm{w} \% \mathrm{H}_{2} \mathrm{O}$ & 4.7 & 78 & $6.2(0.5)$ & No & $\begin{array}{l}\mathrm{NaOH}(-) \\
\mathrm{Na}\end{array}$ \\
\hline & B & $8.4 \mathrm{w} \% \mathrm{H}_{2} \mathrm{O}$ & 6 th. 9 & 43 & $8.5(0.7)$ & No & $\begin{array}{l}\mathrm{NaOH}(-) \\
\mathrm{LiNaCO}_{3}\end{array}$ \\
\hline & 3 & $13 \mathrm{w} \% \mathrm{H}_{2} \mathrm{O}$ & 20 th. 10 & 70 & $5.5(0.7)$ & No & $\mathrm{NaOH}(+)$ \\
\hline & $2^{\text {nd }}$ run & High spread & $22-30$ & 20 & $13.9(1.8)$ & Yes & \\
\hline & 4 & $18 \mathrm{w} \% \mathrm{H}_{2} \mathrm{O}$ & 15 & 44 & $5.1(0.9)$ & Yes (18s) & $\mathrm{NaOH}(+)$ \\
\hline \multirow[t]{3}{*}{ Role of carbonate melting } & 5 & High $\mathrm{T}_{\mathrm{f}}$ & 0.4 & 295 & 8.6 & No & N.O. \\
\hline & 6 & Eutectic mixture & 0.5 & 214 & 7.6 & No & N.O. \\
\hline & 7 & $\mathrm{LiNaCO}_{3}$ & 0.6 & 430 & 10.3 & No & N.O. \\
\hline \multirow{4}{*}{$\begin{array}{l}\text { Direct spreading } \\
\text { extinction }\end{array}$} & 8 & $2.9 \mathrm{w} \% \mathrm{H}_{2} \mathrm{O}$ & 3.1 & 242 & 10 & No & $\mathrm{NaOH}(+) \mathrm{LiNaCO}_{3}$ \\
\hline & 9 & $5.6 \mathrm{w} \% \mathrm{H}_{2} \mathrm{O}$ & 6.9 & 104 & 7.4 & No & $\mathrm{NaOH}(+) \mathrm{LiNaCO}_{3}$ \\
\hline & 10 & $7 \mathrm{w} \% \mathrm{H}_{2} \mathrm{O}$ & 5.4 & 102 & 6.8 & Yes (short) & $\mathrm{NaOH}(+) \mathrm{LiNaCO}_{3}$ \\
\hline & 11 & $13.2 \mathrm{w} \% \mathrm{H}_{2} \mathrm{O}$ & 6.4 & 78 & 5 & Yes $(47 \mathrm{~s})$ & $\begin{array}{l}\mathrm{NaOH}(++) \\
\mathrm{LiNaCO}_{3}\end{array}$ \\
\hline
\end{tabular}

*) th.:then; N.O. = Not Observed.

than in the test with powder 11.

These different results confirmed the tendencies given by tests carried out with continuous spreading conditions (presented in Sections 3.1 and 3.2). In particular, the measurements (temperature decrease rate, time and mass of powder used for extinction) proved that the extinction was faster and more efficient in the case of powders with higher water content. Even if a transient temperature rise was observed at the beginning, the extinction mechanism seemed to be enhanced enough to cancel out this initial reactivity and to finally stop the sodium fire more easily when the content of water of crystallization was more important. Moreover, the presence of $\mathrm{LiNaCO}_{3}$ did not seem to have such an efficient action in the extinction mechanism though its melting was observed after a certain delay.

\section{Discussion}

\subsection{Role of water of crystallization}

For sodium fires, it was shown that the only way to put out a fire is to separate the liquid surface from the air. Decreasing the liquid temperature or blowing the flame appear to be inefficient (Sarrut, 1979). Then, the role of the chemical compound in the powder is to constitute a barrier to limit oxygen supply towards sodium surface, and which may be either solid (but porous) or liquid by the melting of at least one of the component of the powder. The water of crystallization can play this role by reacting with sodium, although this reaction (1) is not anecdotal due to $\mathrm{H}_{2}$ formation and its exothermicity.

\section{Comparison of $T_{p}$ for different water content in continuous spreading}

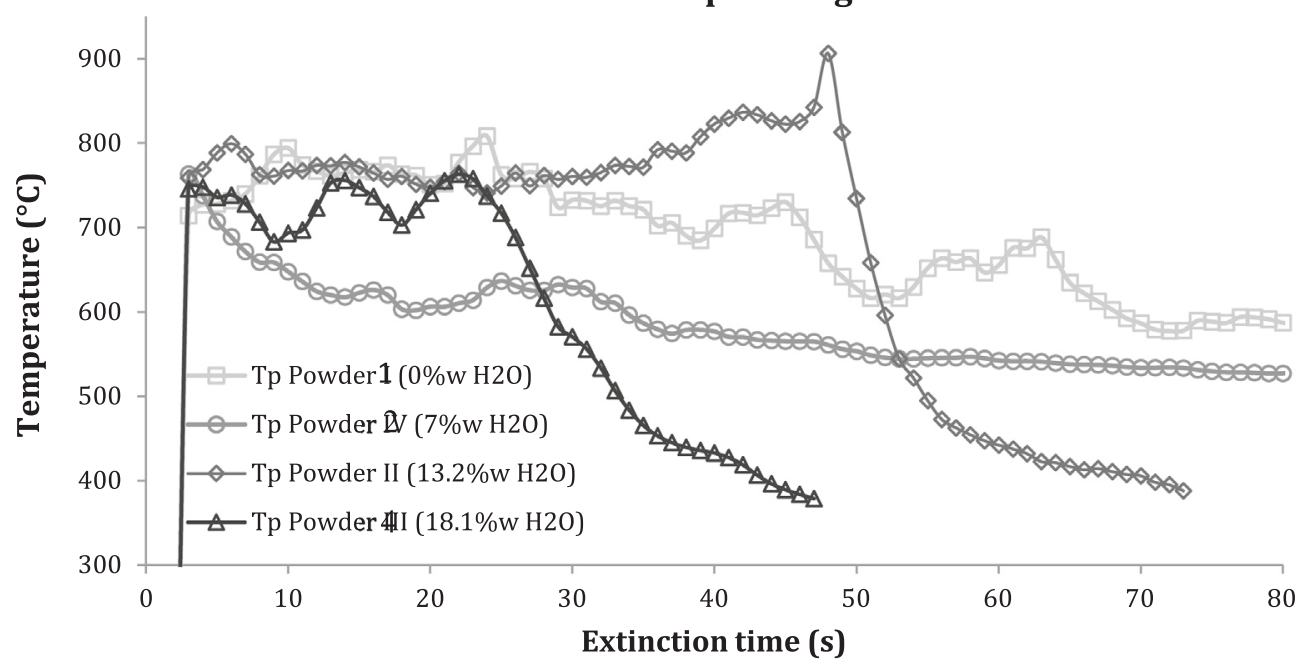

Fig. 5. The comparison of temperature profile recorded by $\mathrm{T}_{\mathrm{p}}$ for different water content in continuous spreading. 


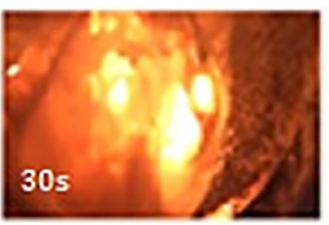

(a)

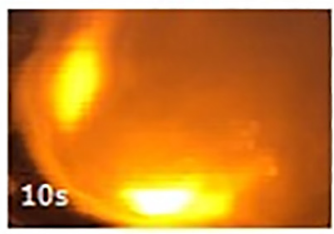

(f)

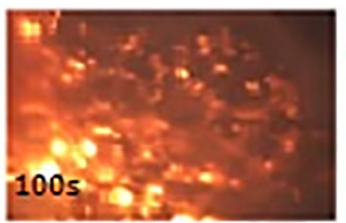

(b)

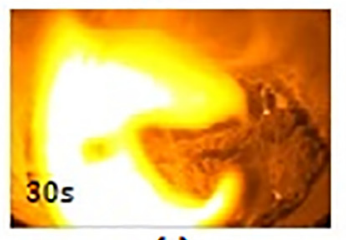

(g)

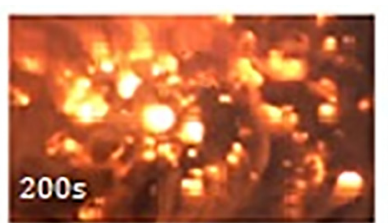

(c)

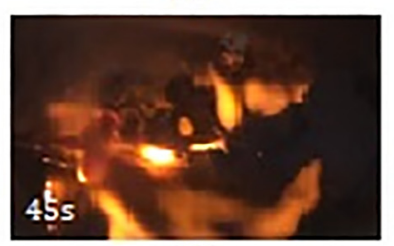

(h)

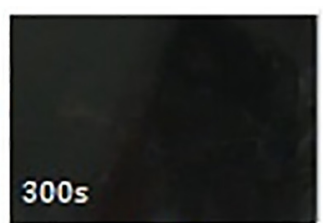

(d)

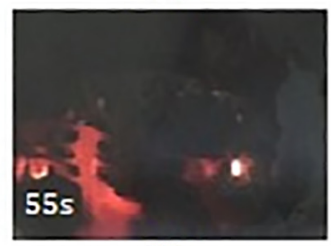

(i)

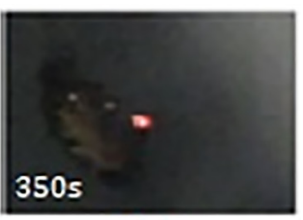

(e)

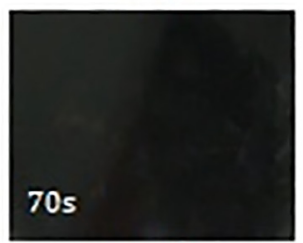

(j)

Fig. 6. The evolution of flame prior to extinction using powder 1 (a-e) and powder $3(f-j)$.

$\mathrm{Na}+\mathrm{H}_{2} \mathrm{O}=\mathrm{NaOH}+1 / 2 \mathrm{H}_{2}$

\subsubsection{Role of liquid $\mathrm{NaOH}$}

A protective layer of liquid sodium hydroxide allows a total separation of sodium and oxygen. $\mathrm{NaOH}$ is liquid above $323^{\circ} \mathrm{C}$ and moreover, an eutectic exists between $\mathrm{NaOH}$ and $7.2 \mathrm{w} \% \mathrm{Na}_{2} \mathrm{CO}_{3}$ at $283^{\circ} \mathrm{C}$. $\mathrm{NaOH}$ is a low viscous fluid (at $500{ }^{\circ} \mathrm{C}$, only twice the viscosity of water at $25^{\circ} \mathrm{C}$ ) (Janz et al., 1983). In addition, the presence of water vapor potentially released by powders heated by sodium fire, is likely to form $\mathrm{NaOH}$ aerosols by reaction with sodium vapor. Since sodium hydroxide is a very hygroscopic compound, these aerosols may turn into deliquescent hydrates. Thus, after $\mathrm{NaOH}$ formation, a liquid barrier can be easily formed on the sodium surface or can fill the porosities of the carbonate. As the melting point is low $\left(283-323^{\circ} \mathrm{C}\right)$, sodium hydroxide should remain liquid during a major part of sodium fire and should prevent efficiently from re-ignition. Moreover, two compounds can be the source of water: sodium carbonate monohydrate and trona.

For the powders of lower water contents, the temperature decrease is slow with no preceding temperature rise (see Fig. 5 for powders 1 and 2). The temperature profile of powders of higher water contents (i.e. powders 3, 4, B and C) tends to demonstrate temperature rises prior to a relatively fast extinction (see Fig. 4 for powder 3 and Fig. 5 for powders 3 and 4). Moreover, the temperatures tend to decrease more rapidly afterwards, down to $350{ }^{\circ} \mathrm{C}$, as compared to the other powders.

It appears that this trend is observed above $5.6 \mathrm{wt} \%$ of water. In Fig. 7, these results were expressed in another form, which consists in the evaluation of the global mass of water of crystallization (that was potentially released during extinction and formed $\mathrm{NaOH}$, see also Table 2) contained in the powder spread over sodium to achieve complete extinction. This figure shows that $0.5-0.9 \mathrm{~g}$ of water is needed to extinguish quickly (in a time around $1 \mathrm{~min}$ ) the sodium pool fire in the conditions (surface area) of our tests. To define relevant extinction criteria, this mass must be reported to the surface area of the sodium pool fire $\left(19.6 \mathrm{~cm}^{2}\right)$. It means that an average of $0.036 \mathrm{~g}$ of water $/ \mathrm{cm}^{2}$ is necessary. It implies that $1-2 \mathrm{~g}$ of $\mathrm{NaOH}$ (equivalent to $0.3-0.6 \mathrm{~mm}$ height of liquid $\mathrm{NaOH}$ for $19.6 \mathrm{~cm}^{2}$ ) is actually required to completely cover the sodium surface. This value is completely consistent with $\approx 0.4 \mathrm{~g}$ of water used to extinguish $12 \mathrm{~cm}^{2}$ of sodium pool fire presented in Reuillon's thesis ( $5 \mathrm{~g}$ of Marcalina with $7.5 \%$ of water of crystallization) (Reuillon, 1976), which represents $0.033 \mathrm{~g}$ of water $/ \mathrm{cm}^{2}$. As what was previously demonstrated by this author, a significant water content is necessary to achieve a complete extinction and our experimental results were in accordance with Reuillon's finding. Extrapolating this results to practical systems, an amount of $\approx 35 \mathrm{~g}$ of water of crystallization contained in the powder is necessary for the extinction of a sodium fire of $1 \mathrm{~m}^{2}$. Experiments on sodium fires of larger areas are in progress. Though the minimal values for the water quantity is not

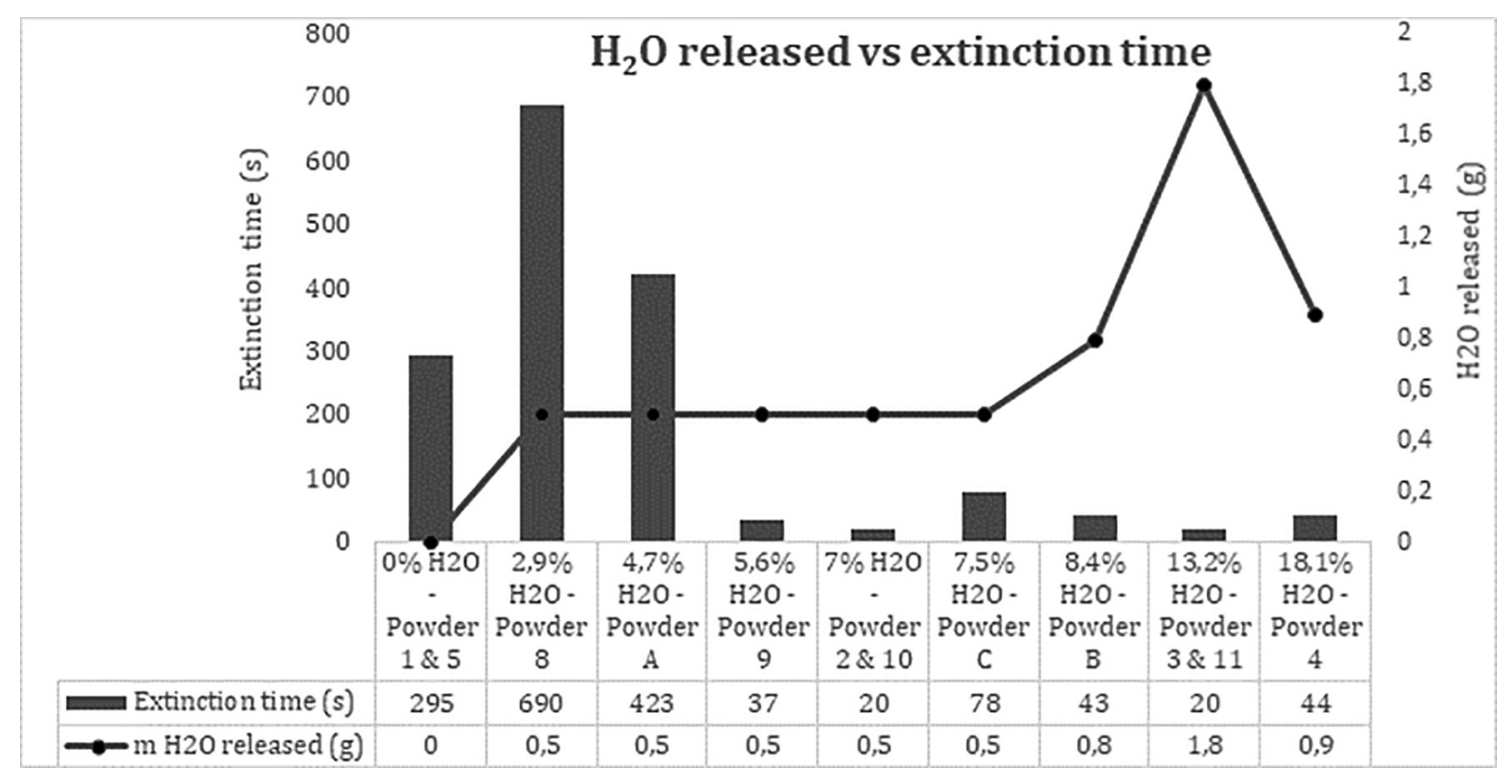

Fig. 7. Mass of hydration water release at extinction time for several powders with different hydration water contents. 
still determined, the tests clearly show the importance of it on the extinction efficiency. As in the experiments on small fires, it is not easy to perform uniform spreading of a powder on a fire, and then the spread quantities generally exceed the one strictly necessary to stop the fire.

Even though there is obviously a slight temperature rise at the beginning of the spreading due to the exothermic reaction of Na with $\mathrm{H}_{2} \mathrm{O}$ at the surface, the fast decrease of temperature shows that the formation of liquid $\mathrm{NaOH}$ plays a key role in the extinguishing performance. Comparing our results between powder $\mathrm{C}$ and powder 10 (cf. Table 2) with similar water content but different compositions, it could be concluded that whatever is the compound containing the water of crystallization, trona of sodium carbonate monohydrate, it can contribute efficiently to the fire extinction.

Powders with insufficient water of crystallization content appear to be only capable to provide a slow smothering effect of the fire with the formation of a porous layer that favors re-ignition. These powders are still able to extinguish a sodium fire, but it may take a much longer time and higher quantity so it questions their efficiency.

The minimum water content, which corresponds to a powder that is still efficient in extinguishing a fire, is $5.6 \mathrm{w} \%$ that is the upper limit range of water contents recommended by the producer several years ago. Meanwhile, powders that are close to $13 \mathrm{w} \%$ of water of crystallization seem more likely to produce a higher flames prior to the (rapid) extinction.

\subsection{2. $\mathrm{H}_{2}$ and the flash flames}

A high rise of temperature recorded by $\mathrm{T}_{\mathrm{s}}$ corresponds to the presence of the flame close to the thermocouple observed in the video (Fig. $6 \mathrm{f}$ and g). It is likely that the higher flames are produced by the burning of the hydrogen from the reaction of water with sodium. It is planned to confirm this assumption by LASER spectrometer measurements in order to detect $\mathrm{H}_{2}$ during the extinguishment of a large sodium fire. Indeed, a higher water content may contribute to a higher production of $\mathrm{H}_{2}$, but produces more liquid $\mathrm{NaOH}$ at the same time. According to Reuillon (Reuillon, 1976), more re-ignitions are observed under the presence of $14.5-15 \%$ water content. Reuillon attributed the flash flames to the spreading mode: direct spreading would increase the quantity of sodium vapor and would provoke a vapor flame. From video observations (e.g. Fig. $6 \mathrm{f}$ and g) and temperature recording in our experiments (Fig. 4, and comparison of behavior with small or high water amounts in Fig. 5), we can more likely correlate the flash flame with the vapor content (chemical effect) than with the spreading mode (physical effect) in the tests. Indeed, the high flames (and temperature rise) were associated with the powders of higher water content, whatever the spreading method was.

An analysis of reaction stoichiometry is carried out in order to understand and to compare the extinction behavior of both compounds containing water: trona and $\mathrm{Na}_{2} \mathrm{CO}_{3} \cdot \mathrm{H}_{2} \mathrm{O}$ The production of $\mathrm{H}_{2}$ is possible for reactions with sodium vapor (reactions (2) and (3)), but not with sodium oxide $\mathrm{Na}_{2} \mathrm{O}$ (reaction (4) and (5), leading to the formation of $\mathrm{NaOH}$ without any $\mathrm{H}_{2}$ production). If the following direct reactions (2) and (3) with sodium vapor is considered, it appears that $0.008 \mathrm{~mol}$ of $\mathrm{NaOH}$ may be produced from $1 \mathrm{~g}$ of trona. The same amount of $\mathrm{NaOH}$ is produced from $1 \mathrm{~g}$ of $\mathrm{Na}_{2} \mathrm{CO}_{3} \cdot \mathrm{H}_{2} \mathrm{O}$ However, the latter produces around 1.6 times less $\mathrm{H}_{2}(0.004 \mathrm{~mol})$ as compared to the one resulting from the reaction with trona $(0.0066 \mathrm{~mol})$. Besides, reactions with $\mathrm{Na}_{2} \mathrm{CO}_{3} \cdot \mathrm{H}_{2} \mathrm{O}$ are less energetic than the ones with trona. This might indicate that $\mathrm{Na}_{2} \mathrm{CO}_{3} \cdot \mathrm{H}_{2} \mathrm{O}$ is a more attractive compound as compared to trona for sodium fire extinction. Therefore, a high content of trona does not seem to actually improve the quality of extinction.

- Direct reaction of $\mathrm{Na}_{2} \mathrm{CO}_{3} \cdot \mathrm{H}_{2} \mathrm{O}$ and trona with $\mathrm{Na}_{(\mathrm{g})}$

$\mathrm{Na}_{2} \mathrm{CO}_{3} \cdot \mathrm{H}_{2} \mathrm{O}_{(s)}+\mathrm{Na}_{(g)} \rightarrow \mathrm{Na}_{2} \mathrm{CO}_{3}+\mathrm{NaOH}_{(l)}$

$$
+\frac{1}{2} H_{2(g)} \quad \Delta H_{r\left(500^{\circ} \mathrm{C}\right)}=-184 \mathrm{~kJ} \cdot \mathrm{mol}^{-1}
$$

$$
\begin{aligned}
\mathrm{Na}_{2} \mathrm{CO}_{3} \cdot \mathrm{NaHCO}_{3} \cdot 2 \mathrm{H}_{2} \mathrm{O}_{(s)}+ & 3 \mathrm{Na}_{(\mathrm{g})} \rightarrow 2 \mathrm{Na}_{2} \mathrm{CO}_{3}+2 \mathrm{NaOH}_{(\mathrm{l})} \\
+ & \frac{3}{2} \mathrm{H}_{2(\mathrm{~g})} \quad \Delta \mathrm{H}_{r\left(500^{\circ} \mathrm{C}\right)}=-650 \mathrm{~kJ} \cdot \mathrm{mol}^{-1}
\end{aligned}
$$

- Direct reaction of $\mathrm{Na}_{2} \mathrm{CO}_{3} \cdot \mathrm{H}_{2} \mathrm{O}$ and trona with $\mathrm{Na}_{2} \mathrm{O}_{(\mathrm{s})}$

$$
\begin{aligned}
\mathrm{Na}_{2} \mathrm{CO}_{3} \cdot \mathrm{H}_{2} \mathrm{O}_{(s)}+\mathrm{Na}_{2} \mathrm{O}_{(\mathrm{s})} & \rightarrow \mathrm{Na}_{2} \mathrm{CO}_{3}+2 \mathrm{NaOH}_{(l)} \quad \Delta H_{r\left(500^{\circ} \mathrm{C}\right)} \\
& =-71 \mathrm{~kJ} \cdot \mathrm{mol}^{-1}
\end{aligned}
$$

$\mathrm{Na}_{2} \mathrm{CO}_{3} \cdot \mathrm{NaHCO}_{3} \cdot 2 \mathrm{H}_{2} \mathrm{O}_{(s)}+3 \mathrm{Na}_{2} \mathrm{O}_{(s)} \rightarrow 2 \mathrm{Na}_{2} \mathrm{CO}_{3}$

$$
+5 \mathrm{NaOH}_{(l)} \quad \Delta H_{r\left(500^{\circ} \mathrm{C}\right)}=-286 \mathrm{~kJ} \cdot \mathrm{mol}^{-1}
$$

The maximum trona content, produced during aging from Marcalina composition, as mentioned in the patent, is predicted to be as much as $58 \mathrm{w} \%$, which would yield $11.6 \mathrm{w} \%$ of water. It is considered as being a slow transformation and to happen faster under a high moisture with no sealed condition (the role of $\mathrm{CO}_{2}$ is important in favoring the reaction) (Kusumanindyah et al., 2015). In tests with 8.4 and $13.6 \mathrm{w} \%$ of water (11.6 w\% being in between) the extinction was fast but preceded by a more or less short temperature increase and higher flames appearing. In the case of a larger sodium fire, it is not expected that the hydrogen flames could be more damageable. Indeed, the same amount of $\mathrm{H}_{2}$ should be released per unit area as on a small fire. Then, though the flames are higher than the sodium flames (generally $2 \mathrm{~cm}$ high), their height should not exceed a few $\mathrm{cm}$. As a consequence, the hazards and the methods for extinction are not dramatically changed. First results on larger fire show that hydrogen flames should not be an issue.

Hence, the complete aging of sodium carbonate into trona could be considered as acceptable in the point of view of extinction efficiency. However, it should be verified that it does not alter too much powder transport properties under different storage conditions. A regular control of moisture, as well as the choice of packaging during storage, would allow controlling the aging.

\subsection{Role of compounds melting at high temperatures (carbonates eutectic)}

Mixed carbonate compound $\mathrm{LiNaCO}_{3}$ in the Marcalina powder was likely produced as a result of a mechanochemical reaction during grinding. It is still questionable whether or not its presence is interesting for improving the extinction efficiency by faster melting as compared to the mixture of lithium and sodium carbonates (in separate grains). The powders with $\mathrm{LiNaCO}_{3}$ as the major component ( ${ }^{\circ} 7,8$ and 9) exhibit a relatively slow melting during extinction, though the sodium surface is above its melting point $\left(500.6^{\circ} \mathrm{C}\right)$, and many re-ignitions were observed.

It was also clear from powders with the eutectic composition but without $\mathrm{LiNaCO}_{3}$ at start (e.g. $\mathrm{n}^{\circ}$ 4), that the carbonates melted, as $\mathrm{LiNaCO}_{3}$ was found in the residue of the powder after extinction. Hence, the melting of the carbonate is not efficient in suppressing the sodium fire by allowing a complete separation of $\mathrm{Na}$ and $\mathrm{O}_{2}$. One of the reason can be that the carbonates are much more viscous than sodium hydroxide (ten times (Newman and Payne, 1978), which might prevent their easy spreading on the sodium surface and the filling of the pores in the remaining powder. One other reason can be that the layer of $\mathrm{Li}$ $\mathrm{NaCO}_{3}$, that forms at freezing when the fire stops, cracks easily, while the sodium temperature is still relatively high enough $\left(\approx 500^{\circ} \mathrm{C}\right)$, which provokes re-ignitions.

It can be concluded that the presence of $\mathrm{LiNaCO}_{3}$ is not mandatory to process an efficient extinguishing powder. The presence of an eutectic itself might not be necessary, at least with sodium at temperature around $500{ }^{\circ} \mathrm{C}$. 


\subsection{Influence of particle sizes on extinction performance}

It was claimed for the ancient sodium fire extinguishing powder, Totalit M2, of particle size $<35 \mu \mathrm{m}$ shows a better performance as compared to other powders of bigger particle sizes (Reuillon, 1976). In her work, Reuillon (Reuillon, 1976) recommended particle sizes to be less than or equal to $160 \mu \mathrm{m}$, whilst several Marcalina batches have a dominant particle size $<63 \mu \mathrm{m}$.

The powders tested in this work have a size range between 5 and $65 \mu \mathrm{m}$ which is still within the range of particle size previously studied. The effect of particle size on the extinction time can be seen in "Supplementary data 2". It appears that particles with smaller sizes (mean particle size $<10 \mu \mathrm{m}$ ) do not contribute to improve the extinction performance unless it has sufficient content of water of crystallization (i.e. $7.5 \mathrm{w} \%$ for powder C $v s 4.7 \%$ for powder A). Likewise, the synthetic powders with the highest water contents perform a better extinction (in terms of extinction time) in comparison to the others with less water, whether their particle sizes are relatively small $(30 \mu \mathrm{m}$, powder 4$)$ or large $(65 \mu \mathrm{m}$, powder 3$)$. This demonstrates the predominant role of chemical composition in achieving efficient sodium fire extinction.

The experimental results clearly demonstrate the little influence of particle size on improving extinction capacity. It might only affect the spreading performance. The smaller particles struggle to form a homogenized layer thickness at the sodium surface since the powder is more cohesive and does not spread easily.

\subsection{Phenomenological description of the extinction mechanism}

Based on the result of the experimental tests discussed above, two contributions for the extinction mechanism might be proposed and illustrated in Fig. 8: (a) the formation of $\mathrm{NaOH}$ and (b) the eutectic melting of carbonates. The phenomenology is proposed as detailed below:

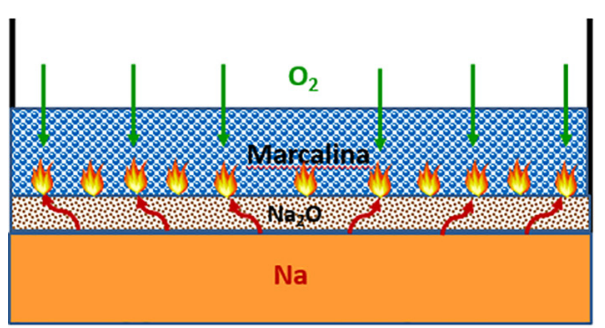

1/ Spreading of Marcalina and diffusion of combustion reactants through porosity

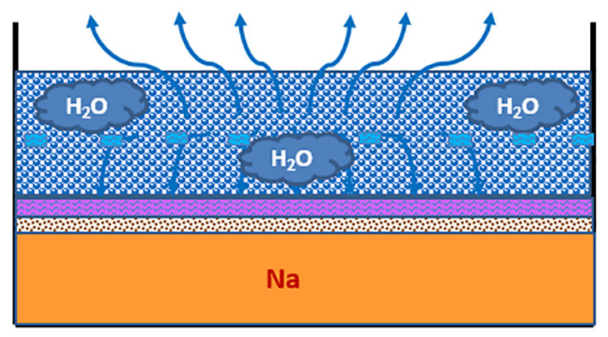

3/ Formation of a liquid $\mathrm{NaOH}$ layer between sodium pool and Marcalina powder
1. The formation of $\mathrm{NaOH}$ (Fig. 8 steps 1 to 3):

- either from a direct formation

o from the reaction of $\mathrm{Na}_{2} \mathrm{CO}_{3} \cdot \mathrm{H}_{2} \mathrm{O}$ with $\mathrm{Na}_{(\mathrm{g})}$ and $\mathrm{Na}_{2} \mathrm{O}_{(\mathrm{s})}$, respectively reactions (2) and (4)

$o$ from the reaction of trona with $\mathrm{Na}_{(\mathrm{g})}$ and $\mathrm{Na}_{2} \mathrm{O}_{(\mathrm{s})}$ : respectively reactions (3) and (5)

- or from indirect formation from the decomposition of trona or $\mathrm{Na}_{2} \mathrm{CO}_{3} \cdot \mathrm{H}_{2} \mathrm{O}$ followed by reaction with $\mathrm{Na}(\mathrm{g}$ )-reaction (1)- or $\mathrm{Na}_{2} \mathrm{O}(\mathrm{s})$.

Assuming the flash flame is an hydrogen flame, it can be stated that there is a significant contributions of direct reactions (2) and (3) or that during indirect formation, part of the released $\mathrm{H}_{2} \mathrm{O}$ reacts with $\mathrm{Na}$ (liquid or gas).

Birchall (1970) proposed an extinction mechanism for methane flames with hydrated alkali salts based on the increase of the specific surface of the powder (physical effect) at product decomposition (water release) reaction. In his case, a sixtyfold increase of specific area was observed, which can account for a large cooling effect. In our experiments, such a large expand at water release was not observed. Instead, this water release rather contributed to the formation of (liquid) $\mathrm{NaOH}$. In addition, the effect of small particle sizes is proved to be insignificant for sodium fire extinction. The mechanisms induce the formation of $\mathrm{H}_{2}$ that might provoke the flash flame observed prior to extinction. These reactions are significantly contributing to the rapid decrease of temperature due to the formation of liquid, low viscous, sodium hydroxide as a protective layer to cover the sodium surface from prolonged contact with oxygen.

2. The melting of eutectic mixture of carbonates (Fig. 8 steps 1,3 and 4)

If the water content is not sufficient to cover all the sodium pool, (as illustrated in Fig. 8 step 4), isolation of the sodium from air can come from the melting of the carbonates. The melting of eutectic mixture of
$\mathrm{Na}$ vapor

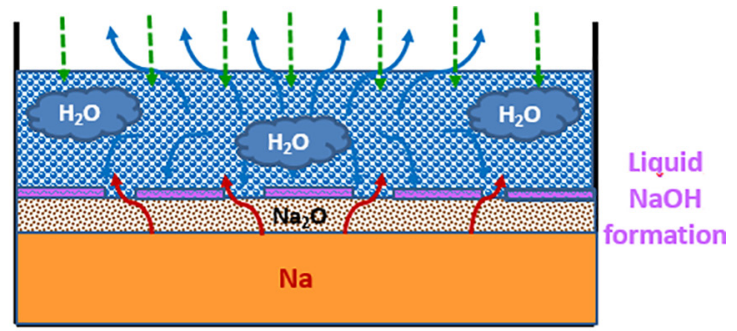

2/ Thermal decomposition of hydrates and diffusion of water vapor through porosity

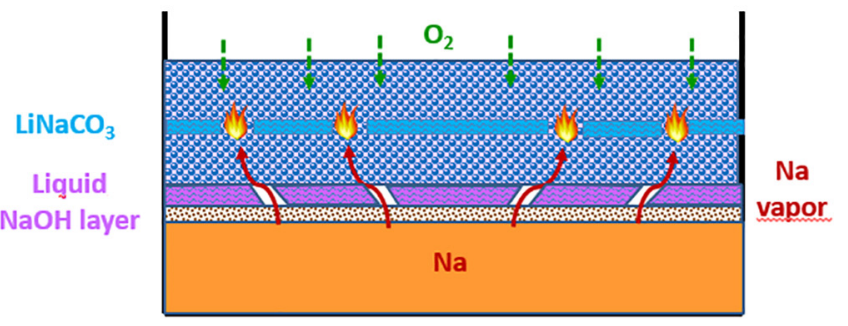

4/ Fusion of $\mathrm{LiNaCO}_{3}$ due to the heat released by residual combustion or $\mathrm{Na}$ oxidation

\begin{tabular}{|c|c|c|c|c|}
\hline Legend: & Na vapor & $\mathrm{O}_{2}$ & Liquid NaOH & LiNaCO $_{3}$ \\
\hline
\end{tabular}

Fig. 8. The mechanism of sodium fire extinction. 
carbonates happened at $500^{\circ} \mathrm{C}$ with the fusion enthalpy of $11.1 \mathrm{~kJ} \cdot \mathrm{mol}^{-1}$. After cooling, $\mathrm{LiNaCO}_{3}$ may be formed according to reaction (6). Hence, the presence of $\mathrm{LiNaCO}_{3}$ is a proof that the melting of eutectic carbonates happened during extinction.

$\mathrm{Na}_{2} \mathrm{CO}_{3(s)}+\mathrm{Li}_{2} \mathrm{CO}_{3(s)} \rightarrow \mathrm{LiNaCO}_{3(l)}$

Liquid carbonate has tenfold higher viscosity than $\mathrm{NaOH}$ (with $\approx 18$ cP (Janz et al., 1980) as compared to $1.8 \mathrm{cP}$ for $\mathrm{NaOH}$ at $500{ }^{\circ} \mathrm{C}$ (Janz, 1988). This property might make the liquid eutectic carbonate less efficient to achieve the formation of a protective layer (uncomplete filling of pores as in Fig. 8 step 3). Besides, the melting reaction happens slower than that of $\mathrm{NaOH}$ formation and requires a higher temperature. Moreover, as the sodium temperature is still high when carbonates solidify, the possible cracking of carbonates layer is likely to provoke re-ignitions (illustrated in Fig. 8, step 4). Consequently, its role is less significant especially if the sodium surface temperature is less or equal to $500{ }^{\circ} \mathrm{C}$ (as it is close to its melting point). However, it can be considered that it could be more efficient for sodium fires with higher sodium surface temperature (more than $500^{\circ} \mathrm{C}$ ), although the problem of the re-ignitions might still arise during sodium/carbonate cooling.

Reuillon tested a ternary mixture of sodium, lithium and potassium carbonates (with hydrated sodium carbonate), which melting point is $390^{\circ} \mathrm{C}$. The mixture melted easily but sank in the sodium (Reuillon, 1976). This might be due to its slightly higher density as compared to sodium-lithium carbonate mixture (at $500{ }^{\circ} \mathrm{C} 2.09$ vs $2.00 \mathrm{~g} \cdot \mathrm{cm}^{-3}$ ) (Janz et al., 1980). Once again, the melting of the carbonates does not appear to be very helpful in extinguishing the fire by comparison of the effect of water (Reuillon, 1976). The main interest in adding lithium carbonate to hydrated sodium carbonate could be to lower the density of the powder and to limit the aging (as $\mathrm{Li}_{2} \mathrm{CO}_{3}$ does not transform) and hence conserve the physical properties of the powder.

\section{Conclusion}

In this study, an analysis of the performance of extinguishing powders was presented to respond potential issues, related to the risk of sodium fires, to be considered in sodium fast reactors. The influence of the chemical composition, the potential aging of different compounds, as well as the role of physical behavior of the powder were analyzed in details in order to propose a consistent description of the extinction mechanism. A series of different extinction tests using the various powders (with real sodium fires at laboratory scale) were carried out to understand the influence of the major parameters of this complex phenomenon.

The results highlighted several points:

- The extinction time is considered to be much longer for powders with no or small amounts of water of crystallization content $(<5.6$ $\% \mathrm{w}$ ). The minimum water content, which corresponds to a powder that is still efficient in extinguishing a fire, is $5.6 \mathrm{w} \%$ that is the upper limit range of water contents recommended by the producer several years ago.

- The water of crystallization appears to play an important role in facilitating the extinction. This is due to the formation of liquid sodium hydroxide thanks to the reaction with sodium and behaving as an insulating layer that ensure the separation of sodium and oxygen. Extrapolating our results to large sodium fires, a minimum amount of $\approx 35 \mathrm{~g}$ of water in the powder per $1 \mathrm{~m}^{2}$ fire surface seems necessary to perform the extinction.

- More water of crystallization contributes to shorten the extinction time. However, a transient increase of temperature and flash flame are observed in certain tests prior to rapid extinction. This temperature rise may correspond to the exothermic reaction of soda and hydrogen production, and the flame to the hydrogen combustion (which should be confirmed by spectrometer measurements). Nevertheless, these detrimental effects are not expected to change dramatically the management of extinction and the hazards for operators. These conclusions have to be confirmed on larger sodium fires (in progress).

- The ageing product trona is proven to not alter the extinction capacity of the powder. With the same amount of sodium hydroxide produced as sodium carbonate monohydrate, trona releases more quantity of $\mathrm{H}_{2}$ and is more exothermic. However this drawback, as noted above, should not prevent the use of the aged powder.

- $\mathrm{LiNaCO}_{3}$ as a main component does not seem to give a significant contribution to the extinction by facilitating the melting of the carbonates.

- When the powder contains no or only few amounts of water, the cracking of the carbonates at solidification and cooling at relatively high temperature $\left(500^{\circ} \mathrm{C}\right)$ may lead to several re-ignitions.

The particle size apparently does not demonstrate a significant contribution in the extinguishing performance except for affecting the spreading before melting (bigger particles behaves better).

In addition to the basic smothering effect due to the spreading of any extinguishing powder, two mechanisms of extinction are then proposed based on the results of these tests:

1. The formation of liquid sodium hydroxide via the direct reaction of trona and/or $\mathrm{Na}_{2} \mathrm{CO}_{3} \cdot \mathrm{H}_{2} \mathrm{O}$ with $\mathrm{Na}_{(\mathrm{g})}$ and/or $\mathrm{Na}_{2} \mathrm{O}_{(\mathrm{s})}$ or indirectly via the decomposition reaction of trona and $\mathrm{Na}_{2} \mathrm{CO}_{3} \cdot \mathrm{H}_{2} \mathrm{O}$ prior to reaction of $\mathrm{H}_{2} \mathrm{O}_{(\mathrm{g})}$ released with $\mathrm{Na}$ and $\mathrm{Na}_{2} \mathrm{O}$.

2. The melting of eutectic mixture of carbonates (less efficient and does not prevent re-ignitions).

This study shows the great importance of the water of crystallization content in the powder in order to have efficient sodium fire extinction. However, the experiments were conducted on small fires $\left(\mathrm{few} \mathrm{cm}^{2}\right.$ ). For the conclusion to be valid in real situation, powders of different water contents should be tested on larger fires. Such tests are in progress. Though the minimal values for the water quantity is not still determined, the tests clearly show the importance of it on the extinction efficiency. As in our experiments, it is not easy to perform uniform spreading of a powder on a fire, and then the spread quantities generally exceed the one strictly necessary to stop the fire.

Finally, it could be concluded that slight modifications in the composition or in the manufacturing of new extinguishing powders would be interesting. The water content in the powder should be increased to match current specifications, so does the particle size, thus limiting the milling process. Both water of crystallization containing compounds should be suitable for sodium fire extinction, sodium carbonate monohydrate brings enough water and less $\mathrm{H}_{2}$ release, trona might be less expensive, less sensitive to aging and $\mathrm{H}_{2}$ excess release appears rather easily manageable.

\section{Acknowledgement}

The authors thank Ai-group for the funding of the $\mathrm{PhD}$ thesis of Ms KUSUMANINDYAH.

\section{Appendix A. Supplementary material}

Supplementary data to this article can be found online at https:// doi.org/10.1016/j.nucengdes.2019.02.017.

\section{References}

Birchall, J.D., 1970. Mechanism of flame inhibition by alkali metal salts. Combust. Flame 14 (1-3), 85.

Cairns, E.J., Macdonald, D.I., 1962. Sensitive thermal analysis establishing formation of incongruently melting compound $\mathrm{LiNaCO}_{3}$. Nature 194 (4827), 441-1000.

Diwakar, S.V., et al., 2011. Numerical prediction of fire extinguishment characteristics of sodium leak collection tray in a fast breeder reactor. Nucl. Eng. Des. 241 (12), 
5189-5202.

Janz, G.J., 1988. Thermodynamic and transport properties for Molten-Salts.Correlation equations for critically evaluated-Density, Surface Tension, Electrical Conductance and Viscosity Data. J. Phys. Chem. Ref. Data 17 (2).

Janz, G.J., Tomkins, R.P.T., 1980. Molten-Salts, vol 5.1. additional single and multicomponent salt systems - electrical conductance, density, viscosity, and surfacetension data. J. Phys. Chem. Ref. Data 9 (4), 831-1021.

Janz, G.J., Tomkins, R.P.T., 1983. Molten-Salts .5.2. additional single and multicomponent salt systems - electrical conductance, density, viscosity and surface-tension data. J. Phys. Chem. Ref. Data 12 (3), 591-815.

Jeong, Y.-C., et al., 2002. Analysis of patents on extinguishing agent for sodium fires. KALIMER Technology Development Team.

Kusumanindyah, N., et al., 2015. Study of the physicochemical properties and the aging phenomena of an extinguishing powder for sodium fire. Récents Progrès en Génie des Procédés 107.

Kusumanindyah, N., 2016. Study of the physicochemical properties of an extinguishing powder for sodium fires: aging, fabrication, and mechanism of extinction. In: ED MEGEP: Génie des procédés et de l'Environnement. Université de Toulouse Ecole
Nationale Supérieure des Mines d'Albi-Carmaux.

Newman, R.N., et al., 1979. Installations for the suppression of sodium fires. Nucl. Energy 18 (5).

Newman, R.N., Payne, J.F.B., 1978. Burning rates of sodium pool fires. Combust. Flame 33 (3), 291-297.

Reuillon, M., et al., 1979. Powder for extinguishing fires of liquid substances or of a mixture of liquid substances. Commissariat, L'energie Atomique A. (Paris, FR) Agence Nationale de Valorisation de la Recherche (ANVAR) (Paris, FR).

Reuillon, M., 1976. Etude de la combustion du sodium et de l'extinction de ses feux par les substances pulvérisées: Role des additifs. In: Chimie Physique, Université d'Orléans. Sakamoto, Y., et al., 2013. Selection of sodium coolant for fast reactors in the US, France and Japan. Nucl. Eng. Des. 254, 194-217.

Sarrut, J.P., 1979. Method of extinguishing metal fires. CECA S.A. (Villacoublay, FR) Le, Carbone Lorraine (Paris, FR) USA.

Schneider, Fast, 2009. breeder reactors in France. Sci. Glob. Secur. 17, 36-53.

Sylvia, J.I., et al., 2012. Development of sodium leak detectors for PFBR. Nucl. Eng. Des. 249, 419-431. 